\title{
Familial Idiopathic Tall Stature
}

National Cancer Institute

\section{Source}

National Cancer Institute. Familial Idiopathic Tall Stature. NCI Thesaurus. Code C118693.

Idiopathic tall stature in a child when either one or both parents is tall in stature. 